\title{
Pentingnya Siklodekstrin dalam Industri Makanan, Kosmetik, dan Farmasi
}

Nasrul Wathoni

Fak ultas FarmasiUniv ersitas Padjadjaran, Sumedang, Jawa Barat, Indonesia

Terbit online : 25 J uni2016

\section{Abstrak:}

Tanpa kita sadari siklodekstrin menjadi senyawa yang penting terutama dalam industri makanan, kosmetika, dan farmasi sebagai bahan pembantu makanan maupun obatnya. Siklodekstrin termasuk dari golongan oligosakarida siklik yang terdiri dari subunit glukopiranosa terikat pada $\alpha-$ $(1,4)$. Pada industri kosmetik, siklodekstrin digunakan untuk meningkatkan stabilitas minyak parfum terhadap oksidasi dan bau. Sedangkan pada industri farmasi, selain mampu meningkatkan kelanutan suatu obat, menurunkan efek toksisitas suatu senyawa, dan sebagai bahan pengkomplek obat seperti vitamin A, E dan $\mathrm{K}$ agar stabil terhadap oksidasi. Selain itu, produk turunannya mampu bertindak sebaga pembawa dalam teknologi nanopartikel terutama dalam aplikasi penghantaran obatbertargetuntuk terapi kanker.

Keyword : Siklodekstrin, kosmetika, industri farmasi

\section{Pendahuluan}

Tanpa kita sadari siklodekstrin menjadi senyawa yang penting terutama dalam industri makanan, kosmetika, dan farmasi sebagai bahan pembantu makanan maupun obatnya.

\section{Apa itu siklodekstrin?}

Siklodekstrin termasuk dari golongan oligosakarida siklik yang terdiri dari subunit glukopiranosa terikat pada $\alpha-(1,4)$. Siklodekstrin memiliki struktur supramolekul seperti kandang atau lubang khusus sama halnya dengan struktur yang dibentuk oleh molekul cryptands, calixarenes, cyclophanes, spherands dan crown ethers.
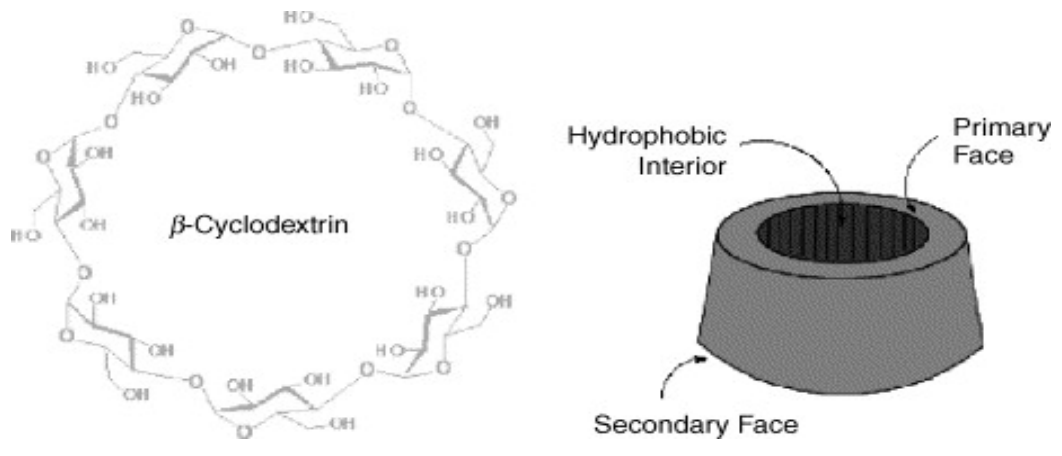

Gambar 1. Siklodestrin (Martin Dell Valle,2003)

Senyawa ini memiliki struktur supramolekul yang bisa bereaksi secara kimia dengan melibatkan interaksi intramolekul seperti ikatan kovalen, ion atau radikal. Mayoritas semua reaksi ini berjenis 'host-guest'. Dibandingkan dengan semua host dari supramolekul yang disebutkan di atas, siklodekstrin menjadi yang terpenting. Karena memiliki kemampuan dalam membentuk inklusi kompleks dan sifat-sifatkompleksnya dapatdimodifikasi secara signifikan. 
Kemampuan dari kompleksasi molekul siłodekstrin membuat banyak digunakan di banyak produk industri, teknologi dan metode analisis. Efek sitotoksik yang bisa diabaikan merupakan atribut penting dalam aplikasi seperti untuk pembawa obat, makanan dan perasa, kosmetik, kemasan, tekstil, proses pemisahan, perlindungan lingkungan, fermentasi dan katalisis.

Sillodekstrin murni dihasilkan dari degradasi starch oleh cycloglycosyl transferase amylases (CGTases) yang diproduksi oleh variasi bacili, di antaranya Bacillus macerans dan Bacillus circulans. Kondisi realsi yang sesuai akan menghasilkan 3 kelompok utama siklodekstrin yaitu: $\alpha-, \beta-$, dan $\gamma^{-}$siklodekstrin yang terdiri atas 6,7 , dan 8 unit $\alpha(1,4)$ - linked $D(+)$-glucopyranose.

\section{Kegunaan Siklodektrin di Industri Makanan, Kosmetik, dan Farmasi}

Dalam industri makanan dan minuman, sikodekstrin digunakan sebagai zat tambahan yang mampu memodifikasi aktivitas kimiawi suatu molekul dengan proteksi suatu gugus tertentu, sebagai penstabil emulsi, menutup bau dan rasa dari bahan makanan serta dapat mengurangi kadar kolesterol.

Tahun 2012, perusahaan makanan Wacker memperkenalkan produk CAVAMAX yang berisi alphasiklodektrin yang diklaim sebagai stabilizer produk makanan untuk vegetarian dan penderita kolesterol. Selain itu, produk ini memungkinkan produsen untuk menghasilkan busa yang stabil di berbagai macam makanan penutup tanpa menggunakan lemak atau protein.

Selang setahun, Wacker meluncurkan produk gamma-siklodektrin yang berasal dari jagung dan kentang sebagai zat tambahan baru pada makanan yang memilik kemampuan untuk menutupi rasa pahit, bebas alergi, dan cocok untuk vegetarian.

Pada industri kosmetik, sikodekstrin digunakan untuk meningkatkan stabilitas minyak parfum terhadap oksidasi dan bau. Sedangkan pada industri farmasi, selain mampu meningkatkan kelarutan suatu obat, menurunkan efek toksisitas suatu senyawa, dan sebagai bahan pengkomplek obat seperti vitamin $A, E$ dan $\mathrm{K}$ agar stabil terhadap oksidasi. Selain itu, produk turunannya mampu bertindak sebagai pembawa dalam teknologi nanopartikel terutama dalam aplikasi penghantaran obat bertarget untuk terapi kanker.

Sumber :

A. N. Bestari, PENGGUNAAN SIKLODEKSTRIN DALAM BIDANG FARMASI. Majalah Farmaseutik, Vol. 10 No. 1 Tahun 2014 .

J. D. Dziezak, Microencapsulation and encapsulated ingredients, Food Technol. 42(4): 136 (1988)

E. M. Martin Del Valle. Cyclodextrins and their uses: a review. Process Biochemistry Volume 39, Issue 9, 31 May 2004, Pages 1033-1046

http://www.wacker.com/cms/en/press media/pressreleases/archive 2013/pressinformation 2013 detail 44672.jsp. Diakses 25 Juni 2016. http://www.foodnavigator.com/Policy/Wacker-wins-EU-approval-for-novel-ingredient. Diakses 25 Juni 2016. 